DOI: $10.11649 / a .1513$

Article No.: 1513

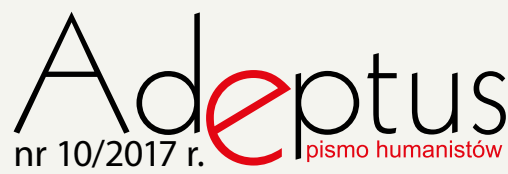

Iwona Zielińska - socjolożka, absolwentka Szkoły Nauk Społecznych PAN oraz działaczka w Polskim Towarzystwie Socjologicznym. Od 2012 roku pracuje na stanowisku adiunkta w Akademii Pedagogiki Specjalnej, gdzie prowadzi zajęcia m. in. z socjologii komunikacji. W pracy naukowej zajmuje się paniką moralną, badaniem dyskursów medialnych, a ostatnio także kontrowersjami technologicznymi i komunikacją naukową.

e-mail: izielinska@aps.edu.pl

Iwona Zielińska

\title{
Wpływ mediów społecznościowych na komunikację naukową: strategie przeciwników GMO na Facebooku
}

\section{Wstęp}

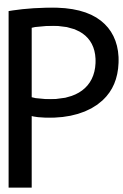

ojawienie się nowych narzędzi komunikacyjnych wraz z rozwojem Web 2.0 zapoczątkowało proces „odmasowiania” informacji, które coraz częściej dostosowane są do indywidualnych gustów, potrzeb czy światopoglądów odbiorców (Chaffee \& Metzger, 2001). Inaczej niż w klasycznych modelach komunikacji masowej, gdzie adresat przekazu jest zwykle pasywnym odbiorcą, współczesna komunikacja internetowa powoduje, że nadawca nie tylko odbiera, ale też komentuje, redaguje, nadaje (np. udostępnia innym), a nawet współkształtuje wiadomość. Staje się normą, że w głównych wydaniach wiadomości telewizyjnych czy radiowych relacjonowane są zdarzenia mające swe źródło w mediach społecznościowych, takich jak Facebook czy Twitter. Newsem mogą być zarówno reakcje użytkowników na kontrowersyjne tematy, jak też realne działania, np. spontanicznie zorganizowane protesty, jak czarny protest, zorganizowany jesienią 2016 roku w Polsce, jako wyraz sprzeciwu wobec ustawy mającej na celu zaostrzenie przepisów dotyczących aborcji. Przed przejściem do zasadniczego tematu artykułu, warto jednak uściślić znaczenie, w jakim termin media społecznościowe (social media) jest używany 
w tekście. Nie komplikując zbytnio sprawy, o co skądinąd bardzo łatwo (zob. Toczyski, 2014), odwołam się do często cytowanej definicji, która mówi o grupie aplikacji tworzonych na podwalinach Web 2.0, „które pozwalają na tworzenie i wymianę treści tworzonych przez użytkowników" (Toczyski, 2014, s. 61).

Wspomniane na początku przemiany w świecie mediów i komunikowania w ogóle widoczne są także w komunikacji naukowej (science communication). Komunikację naukową rozumiem jako praktykę społeczną - publiczne promowanie i objaśnianie nauki i techniki oraz praw naukowych nie tylko przez naukowców, ale także przez dziennikarzy oraz amatorów (nienaukowców) za pomocą dostępnych narzędzi (por. Kulczycki, 2012). Jest to pojęcie znacznie szersze niż popularyzacja nauki, która w swej istocie ma charakter edukacyjny. W ramach tak rozumianej komunikacji naukowej mieści się także dyskutowanie i kwestionowanie dominujących wyników badań naukowych. W konsekwencji prowadzi to do konfliktów technologicznych i naukowych (zob. Stankiewicz, 2011), dotyczących takich zagadnień jak tytułowe organizmy genetycznie modyfikowane (GMO), szczepionki czy elektrownie jądrowe. Tradycyjne media masowe, czyli radio, telewizja i prasa, wyraźnie faworyzują dominujący dyskurs naukowy', reprezentowany głównie przez naukowców i ekspertów (Bucchi, 2004; Bucchi \& Mazzolini, 2003). Tylko w sytuacjach kontrowersyjnych, takich jak naukowe dysputy, spory czy afery, do głosu dopuszczane są także alternatywne opinie na dany temat, głównie w celu dalszego wzbudzania kontrowersji, a więc i płynących z nagłaśniania sprawy profitów (Bucchi, 2004), np. korzyści finansowych płynących ze zwiększenia sprzedaży czasopisma.

Niniejszy tekst zwraca uwagę na zmianę dynamiki w komunikacji naukowej, powodowanej wykorzystywaniem mediów społecznościowych. Skupię się głównie na włączaniu się $w$ ten proces nowych aktorów, niedopuszczanych wcześniej przez media głównego nurtu, zwłaszcza takich, którzy nie zajmują się profesjonalnie nauką, ale z pewnych powodów - takich jak na przykład obawa przed skutkami zastosowania nowych technologii - uczestniczą w kształtowaniu dyskursu naukowego. Przykładem, który posłuży ilustracji wykorzystywanych strategii komunikacyjnych, będzie utworzona na Facebooku grupa oddolna („społeczność" w nomenklaturze Facebooka) o nazwie "GMO To Nie To", której celem jest sprzeciw wobec stosowania nasion i żywności genetycznie modyfikowanej.

\footnotetext{
${ }^{1}$ Termin „nauka” stosowany jest w tekście w szerokim ujęciu, z włączeniem weń technologii (np. inżynierii genetycznej), kwestii medycznych, a także tych związanych ze środowiskiem.
} 


\section{Komunikacja typu Web $\mathbf{2 . 0}$}

Terminem Web 2.0 określa się nowego rodzaju treści online, które są tworzone, modyfikowane, usuwane przez użytkowników internetu. W efekcie pojawia się otwarta przestrzeń, w której zatarta zostaje granica pomiędzy nadawcą i odbiorcą. Jest to zasadnicza różnica pomiędzy Web 2.0 a tradycyjną komunikacją masową, gdzie role nadawcy i odbiorcy są sztywno określone. Produktem tego rodzaju komunikacji jest Wikipedia, YouTube, fora dyskusyjne czy sieci społecznościowe - Twitter, Istagram, Facebook, Pinterest i wiele innych. Serwis internetowy Web 2.0 wprowadził więc większą reprezentację opinii na różne tematy, w tym także te dotyczące nauki i technologii. Będąc daleko bardziej dostępnym medium (choć nadal mniej demokratycznym niż początkowo sądzono), internet stał się miejscem, w którym alternatywne dyskursy naukowo-technologiczne mają dziś swój początek, są rozbudowywane i propagowane przez media społecznościowe, w tym blogi i fora. Mają też liczne grono odbiorców. Coraz częściej bowiem internet stanowi naturalne źródło informacji pierwszego wyboru, zwłaszcza - jak pokazują badania - w kwestiach dotyczących zdrowia (Choudchury, Morris, \& White, 2014). Czy będzie to rodzic niemowlaka, który zastanawia się nad ryzykiem związanym ze szczepieniami, pacjent oczekujący na transplantację, czy nastolatek poszukujący informacji na temat wstydliwych objawów, jakie u siebie zauważył. Badania prowadzone na początku 2016 r. pokazują, że chociaż dla większości Polaków (71\%) głównym źródłem informacji są wiadomości telewizyjne, to dla osób w wieku do 40 roku życia rolę tę przejmuje już internet (TNS Global, 2016). W tym samym badaniu aż 56\% respondentów deklaruje, że interesuje się nauką i technologią. Amerykańskie badania pokazują natomiast, że głównym źródłem informacji ze świata nauki i technologii są media społecznościowe: YouTube, Twiter i Facebook (National Science Board, 2014). Sytuacja ta wskazuje również na konieczność przesunięcia zainteresowań badaczy komunikacji naukowej z mediów tradycyjnych na internet. Obecnie w naukach społecznych mamy do czynienia z paradoksalną sytuacją: pomimo powszechnego stosowania i produkcji dużej ilości danych przez użytkowników Web 2.0, wciąż zauważalny jest silny niedobór analiz socjologicznych wykorzystujących wielość łatwo dostępnych danych, także w wypadku dynamiki komunikacji naukowej i technologicznej. Tymczasem pomijanie zachowań online przez badaczy powoduje, że zaniedbany zostaje istotny aspekt wielu współczesnych zjawisk społecznych.

Zanim przejdę do szczegółowego omówienia strategii komunikacyjnych organizacji oddolnych, angażujących się w komunikację naukową na temat GMO, zobaczmy, jakie są podstawowe różnice w strategiach komunikacyjnych stosowanych przez obie strony 
sporu o GMO, tzn. przez zwolenników GMO, reprezentowanych głównie przez naukowców i ekspertów (np. badaczy) oraz niektórych dziennikarzy², a także przez przeciwników GMO, reprezentowanych przez ekologów, rolników oraz inne osoby zainteresowane wpływem GMO na zdrowie i środowisko. Przedstawione w tabeli informacje są wynikiem przeprowadzonej przeze mnie obserwacji zachowań online.

Tabela 1. Strategie komunikacji naukowej zwolenników i przeciwników GMO. Źródło: badanie własne luty-kwiecień 2015.

\begin{tabular}{|c|c|c|}
\hline & Pro-GMO & Anty-GMO \\
\hline $\begin{array}{l}\text { Organizacja } \\
\text { działań }\end{array}$ & $\begin{array}{l}\text { Słaba - rozproszone komunikaty z różnych } \\
\text { źródeł rzadko powołujących się na siebie } \\
\text { nawzajem }\end{array}$ & $\begin{array}{l}\text { Mocna - pojedyncze organizacje i inicja- } \\
\text { tywy tworzą koalicje, podejmują wspólne } \\
\text { działania, cytują się nawzajem, wzmacniając } \\
\text { przekaz }\end{array}$ \\
\hline $\begin{array}{l}\text { Częstotliwość } \\
\text { przekazu }\end{array}$ & $\begin{array}{l}\text { Rzadka, przekaz zazwyczaj pojawia się jako } \\
\text { reakcja na jakieś wydarzenia, np. zmiana } \\
\text { legislacji w } 2015 \text { r. }\end{array}$ & $\begin{array}{l}\text { Regularny, stały przekaz, zintensyfikowany } \\
\text { przy okazji jakiegoś wydarzenia }\end{array}$ \\
\hline $\begin{array}{l}\text { Obszar działal- } \\
\text { ności }\end{array}$ & Media mainstreamowe, internet & $\begin{array}{l}\text { Internet oraz protesty na ulicach, zbieranie } \\
\text { podpisów pod petycjami }\end{array}$ \\
\hline $\begin{array}{l}\text { Wykorzystanie } \\
\text { social mediów }\end{array}$ & $\begin{array}{l}\text { Słabe (największa grupa pro-GMO na Face- } \\
\text { booku liczy ponad } 100 \text { osób) }\end{array}$ & $\begin{array}{l}\text { Bardzo duże (największa grupa na Facebo- } \\
\text { oku liczy ponad } 7000 \text { osób) }\end{array}$ \\
\hline Wsparcie & $\begin{array}{l}\text { Instytucje naukowe i badawcze, eksperci, } \\
\text { naukowcy, media }\end{array}$ & $\begin{array}{l}\text { Celebryci, pojedynczy naukowcy, organiza- } \\
\text { cje pozarządowe, niektórzy politycy }\end{array}$ \\
\hline Typ narracji & $\begin{array}{l}\text { „racjonalny"- odwołujący się do faktów, } \\
\text { badań, wykorzystujący pozytywne scena- } \\
\text { riusze zastosowania GMO }\end{array}$ & $\begin{array}{l}\text { "emocjonalny" - wykorzystuje czarne } \\
\text { scenariusze skutków zastosowania GMO, } \\
\text { odwołuje się do badań (mniej znanych lub } \\
\text { celowo nieujawnianych) }\end{array}$ \\
\hline
\end{tabular}

Algorytmy wykorzystywane w sieciach społecznościowych typu Facebook stale „uczą się" o naszych wyborach, zainteresowaniach i sposobach wykorzystywania multimediów online. Informacje te algorytm przetwarza w taki sposób, by podsuwać nam treści podobne do tych, które w jakiś sposób zwróciły wcześniej naszą uwagę, i które są spójne z już przyjętymi opiniami i postawami, co w efekcie jeszcze bardziej wzmacnia te opinie i postawy. Polubienie jakiejś informacji umieszczonej np. na stronie "Crazy Science" spowoduje więc, że informacje z tej strony będą pojawiały się częściej na naszej tablicy na Facebooku. Skomentowanie wyborów prezydenckich w USA zapewne zwiększy na tablicy ilość informacji (z różnych źródeł) na temat

\footnotetext{
2 Przykładem może być blog dziennikarza „Polityki” Wojciecha Zalewskiego pt. GMObiektywnie, na którym zamieszczane są informacje o GMO na podstawie badań, opracowań i raportów, które pokazują pozytywne aspekty stosowania w uprawach roślin genetycznie modyfikowanych.
} 
wyborów w USA i tak dalej. Taki sposób zindywidualizowania informacji powoduje, że zamiast śledzić wiele różnorodnych wiadomości, użytkownicy mediów społecznościowych otaczają się informacjami na wybrane tematy, które dodatkowo są zgodne z ich wcześniejszymi opiniami. W psychologii społecznej wykorzystuje się pojęcie „efektu potwierdzenia” - który jest jednym z błędów poznawczych (Plous, 1993) - aby opisać tendencje do wyszukiwania informacji, które potwierdzą istniejące u odbiorcy uprzedzenia lub opinie. W rzeczywistości jednak inne zjawisko, określane jako „efekt niepotrzebnych informacji” (information bias), pokazuje tendencję do wyszukiwania dużej ilości informacji, które teoretycznie miałyby pomóc w podjęciu decyzji (bądź rozstrzygnięciu jakiegoś dylematu). Tymczasem badania dowodzą, że ilość informacji nie wpływa znacząco na decyzję (Vaughan, 2013). Algorytmy wykorzystywane przez media społecznościowe (śledzenie naszego zachowania w internecie) umożliwiają i wzmacniają działanie zarówno efektu niepotrzebnych informacji, jak i efektu potwierdzenia.

Nawiązując do tytułowego zagadnienia, przyjrzę się teraz strategiom wykorzystywanym przez jedną z największych (tzn. posiadających największą liczbę polubień3) społeczności facebookowych, które prowadzą kampanie przeciwko organizmom i żywności modyfikowanej genetycznie. Grupa ta nazywa się GMO To Nie To (GTNT). W dziale „Informacje” przeczytamy, że GTNT jest całkowicie oddolną i apolityczną inicjatywą społeczną, zrzeszającą cały przekrój społeczeństwa polskiego, a nie tylko ekologów, jak zaznaczają anonimowi autorzy profilu. Główny cel, jaki sobie stawiają, to „zbudować jak najszerszą świadomość obywatelską w kwestii GMO”" ${ }^{4}$. Działacze inicjatywy GTNT podkreślają również, że ich protest dotyczy stosowania inżynierii genetycznej w nasionach i żywności, natomiast nie w medycynie czy farmacji, np. do produkcji insuliny. Taka postawa jest zresztą zbieżna z ogólnym stosunkiem większości Polaków do GMO (zob. Centrum Badania Opinii Społecznej, 2013).

\section{Strategie komunikacji (anty)GMO na Facebooku}

Obserwując działania komunikacyjne GTNT, posłużyłam się jednym z modeli - modelem SUCCESS (Heath \& Heath, 2007; Yeo, 2015), który wypracowany został, by pomóc naukowcom i ekspertom w lepszym posługiwaniu się narzędziami online w celu propagowania i popularyzowania wiedzy naukowej. Model ten łączy zalecenia ogólne dotyczące komunikacji

\footnotetext{
${ }^{3} 7292$, dane na 15.06.2017.

${ }^{4}$ Zob. GMO To Nie To (b.d.).
} 
naukowej z wykorzystaniem mediów masowych (zob np. Christensen, 2007), z uwzględnieniem jednocześnie specyfiki internetowych narządzi komunikacji. SUCCESS jest skrótowcem utworzonym $z$ angielskich określeń pięciu podstawowych warunków, jakie powinna spełniać dobrze przygotowana informacja naukowa: Simple - prosta, Unexpected - nieoczekiwana, Concrete - konkretna, Credible - wiarygodna, Emotional - emocjonalna oraz Stories - opowieści, tj. wykorzystująca pewną historię. Obserwując działania administratorów GTNT, chciałam sprawdzić, czy (a jeśli tak, to w jaki sposób) zasady te są obecne w komunikacji naukowej GTNT zapośredniczonej przez Facebooka.

Zasada dotycząca prostego przekazu nie oznacza, że dany temat ma zostać zbanalizowany. Chodzi tu o umiejętność przekazywania abstrakcyjnych teorii czy też dużej liczby danych empirycznych w jasny, czytelny i zrozumiały dla odbiorcy sposób, bez używania nazbyt technicznego czy specjalistycznego żargonu. Pewnych trudności może nastręczać fakt, że wiele słów funkcjonujących w języku potocznym ma zupełnie inne znacznie w języku specjalistycznym. Dobrą ilustracją tego zjawiska na przykładzie socjologii jest termin „instytucja”. W znaczeniu powszechnym instytucja jest rozumiana jako pewnego rodzaju organizacja, np. ZUS. W socjologii zaś instytucja to ogólnie przyjęte formy działalności lub współżycia społecznego, np. rodzina. Zadanie upraszczania tematu jest jednym z najtrudniejszych dla osób profesjonalnie zajmujących się nauką, gdyż często towarzyszy im przekonanie, że niuanse i szczegóły są niezwykle ważne dla całościowego przekazu idei (Yeo, 2015). Z kolei takie nadmierne skupienie się na szczegółach nie pomaga laikom w zrozumieniu istoty rzeczy.

Z prowadzonych w trakcie badania obserwacji wynika, że administratorzy strony GTNT nie mają problemu z zastosowaniem zasady prostego przekazu w praktyce. Nie znaczy to jednak, że przekaz ten adresowany jest do niewykształconego odbiorcy, o czym świadczy fakt, że często do skrótowej informacji, relacjonującej w uproszczony sposób wyniki jakiegoś badania, podany jest link do źródła w języku angielskim, co sugeruje, że nadawcy zakładają pewne kompetencje wśród członków grupy, związane albo ze znajomością języka angielskiego, albo z korzystaniem z narzędzi, które ułatwią im zaznajomienie się z treścią (np. translator Google). Na przykład wyniki niemieckich badań przedstawiono w następujący sposób:

\section{Szokujące dane!}

Fundacja Heinricha Bölla przeprowadziła szeroko zakrojone testy sprawdzające zawartość glifosatu - środka uznanego za potencjalnie rakotwórczy - w moczu obywateli Niemiec. Przebadano 2009 osób. U 3/4 poziom stężenia glifosatu był 5 razy większy 
niż dopuszczony prawnie maksymalny limit zawartości glifosatu w wodzie pitnej. U aż 1/3 z badanych stężenia przekraczały bezpieczny poziom zawartości określony dla wody 10 do nawet 42 razy. Glifosat znaleziono w moczu 99,6\% badanych.

Informacja ta została udostępniona 15 razy, co jest dość wysoką liczbą w porównaniu do innych postów ze strony, choć nie najwyższą. Np. raport na temat umowy CETA udostępniony został aż 41 razy. Badania pokazują, że to, czy dany post zostanie przekazany dalej, zależy od emocji, jakie budzi. Największy wpływ na dalsze udostępnianie danego postu przez użytkowników Facebooka (tzw. „szerowanie”) mają zdziwienie, złość, niepokój oraz zaskoczenie (Berger \& Milkman, 2012).

Jedną z technik upraszczających przekaz jest zastosowanie schematów poznawczych. Są to abstrakcyjne struktury wiedzy przechowywane w pamięci, które używane są do selekcji i interpretacji nowych informacji. W socjologii fenomenologicznej określa się je jako podręczny zasób wiedzy. Innymi słowy, ludzie starają się znaleźć powiązania między nowo napotkaną informacją a istniejącymi w ich umysłach schematami. Przykładem wykorzystania schematów mentalnych jest kampania Greenpeace przeciwko GMO, w której przywołano obraz monstrum stworzonego drogą eksperymentów naukowych przez fikcyjnego naukowca o nazwisku Frankenstein. Odwołanie do historii Frankensteina ma przypominać i ostrzegać, co się może zdarzyć, kiedy naukowcy (tu genetycy) ingerują w naturę. Skojarzenie proste, ale bardzo wymowne.

Druga zasada udanej komunikacji naukowej wskazuje na element zaskoczenia. Jej zastosowanie ma na celu przyciągnięcie i utrzymanie uwagi widza. GTNT najczęściej wykorzystuje tę zasadę, publikując posty, które sugerują ujawnienie jakiegoś sekretu albo informacji, którą wielkie instytucje (np. korporacje, Komisja Europejska, rządy państw) próbują ukryć przed ludźmi. 4 października 2015 opublikowany został post pod tytułem „Autor zachwalającego zalety GMO artykułu, profesor Harvardu, nie ujawnił swoich związków z koncernem Monsanto. Śliskie rejony nauki”. Inny przykład pokazujący wykorzystywanie zasady zaskoczenia, to opublikowany 7 kwietnia 2016 r. na Facebooku GTNT post o następującej treści: „Proces oceny GMO w UE jest wadliwy, ogromne sumy pompowane we wspieranie technologii, której bezpieczeństwo ocenia się nie dość sumiennie". I dalej link do artykułu ze strony zielonewiadomosci.pl, w którym instytucje europejskie krytykowane są za zbyt mały wysiłek włożony w ocenę ryzyka związanego ze stosowaniem modyfikacji genetycznych, przy jednoczesnych miliardowych nakładach 
na rozwój samej technologii. Artykuł zdaje się sugerować, że być może przemysł GMO wywiera na UE większe naciski ${ }^{5}$.

Zasada dotycząca konkretu bazuje na przeświadczeniu, że odbiorca informacji łatwiej tworzy sobie wyobrażenie na dany temat na podstawie konkretnych (zamiast abstrakcyjnych) danych. I w tym względzie, podobnie jak w upraszczaniu przekazu, osoby amatorsko zajmujące się komunikacją naukową mają przewagę nad naukowcami i ekspertami. GTNT stosuje tę zasadę, przywołując dane liczbowe albo wskazując na konkretne skutki uboczne używania GMO w rolnictwie, takie jak zubożenie bioróżnorodności czy zatruwanie sąsiednich upraw.

Czwarta zasada dotyczy wiarygodności informacji oraz rzetelności osoby, która te informacje komunikuje. W komunikacji naukowej realizowanej przez ekspertów zasada ta wdrażana jest automatycznie poprzez, na przykład, pokazanie afiliacji eksperta z zaufaną instytucją (Yeo, 2015), np. Polską Akademią Nauk czy Uniwersytetem Warszawskim. Nie-ekspertom zazwyczaj brakuje tego rodzaju instytucjonalnego wsparcia. Zwłaszcza gdy silnie podkreślają oni swoją niezależność od jakichkolwiek organizacji politycznych, ekonomicznych i ciał badawczych, jak w przypadku inicjatywy GTNT. W takiej sytuacji trzeba więc znaleźć inne sposoby legitymizujące wiarygodność przekazu. W omawianym przypadku komunikacji naukowej udało mi się wyodrębnić cztery takie strategie uwiarygodniające:

1. Sięganie po wsparcie tych naukowców, którzy kwestionują bezpieczeństwo stosowania GMO. W tym wypadku głównym autorytetem środowisk anty-GMO jest prof. Gilles-Eric Séralini. W 2012 roku Séralini opublikował kontrowersyjne wyniki swoich badań na szczurach karmionych genetycznie modyfikowaną kukurydzą, wskazując na liczne negatywne skutki uboczne, w tym olbrzymie guzy, jakie pojawiły się u gryzoni. Artykuł na ten temat ukazał się w uznanym czasopiśmie naukowym, ale pod wpływem licznych zarzutów dotyczących sposobu przeprowadzania eksperymentu został wycofany i ponownie opublikowany w innym miejscu.

2. Powoływanie się na te wyniki badań, które potwierdzają stanowisko GTNT, że stosowanie GMO może być szkodliwe, np. wyniki z eksperymentu Séraliniego, albo przywołane wyżej badania niemieckie o obecności glikosatu w moczu.

${ }^{5}$ Zob. „Europejscy Zieloni: Proces oceny GMO w UE jest wadliwy” (2016). 
3. Podkreślanie roli wiedzy naukowej w przestawianym przez GTNT stanowisku na temat GMO. Na przykład w dziale „Informacje” możemy przeczytać, że „Na stronie GMOTO NIE TO wymieniamy się wiedzą dotyczącą upraw GM i żywności GM. W dziale "Dyskusje" można znaleźć wiele artykułów przywołujących wyniki badań „(...)Odwołujemy się do rzeczowych argumentów, nie zaś emocji”. W wypadku komunikacji eksperckiej wykorzystanie wiedzy naukowej jest uznawane za normę i oczywistość, dlatego rzadko można spotkać eksperta-naukowca, który przekonuje, że posługuje się wiedzą. Bardziej prawdopodobne może być podkreślanie jakości wiedzy, jaką posługuje się ekspert, poprzez używanie takich określeń jak „wiarygodne badania" czy "rozstrzygające dowody".

4. Wspieranie sprawy przez celebrytów i artystów. W dziale "Informacje" znajduje się lista zorganizowanych przez inicjatywę obywatelską GTNT wydarzeń, a wśród nich apel podpisany przez artystów, m.in. Urszulę Dudziak, braci Waglewskich (Fisz i Emade), członków zespołu Sistars. Nie ma natomiast informacji, czego dotyczył ów apel, co sugeruje, że ważniejsze było pokazanie konkretnych nazwisk niż treści apelu. Na Facebooku GTNT znajduje się także krótkie wideo, w którym znany kucharz Kurt Scheller wyjaśnia, dlaczego nie używa produktów GMO w kuchni. Znane osoby pełnią tu funkcję autorytetu, czyli zastosowany został jeden z mechanizmów wpływania na ludzi (Cialdini, 1996). Mówiąc ogólnie, zasada ta pokazuje, że w sytuacjach, kiedy jednostce brakuje wiedzy lub kompetencji w jakiejś kwestii, automatycznie poszukuje ona autorytetu do naśladowania. Ten konkretny przykład pokazuje, że legitymizowanie działań GTNT przez znane osoby jest gwarancją rzetelności tych działań. Posługuję się tu jednak tylko moją intuicją badawczą; przedstawione sugestie wymagają dalszych badań i weryfikacji.

Kolejną zasadą udanej komunikacji naukowej jest emocjonalny przekaz. Autorzy modelu SUCCESS twierdzą, że te idee i wiadomości, które zawierają pewien ładunek emocjonalny, „przywierają" mocniej i dłużej do świadomości odbiorcy (Heath \& Heath, 2007). Istnieją dwa sposoby zwiększania wpływu emocji na przekaz. Po pierwsze poprzez odwołanie się do interesów osobistych jednostki, pokazując na przykład, jaki wpływ ma GMO na zdrowie osobiste. Wyliczanie zagrożeń zdrowotnych wynikających ze stosowania genetycznie modyfikowanej żywności oraz herbicydu Roundup to strategia najczęściej stosowana przez GTNT. Druga taktyka polega na odwołaniu się do tożsamości kulturowej i narodowej, np. polskiej ziemi 
czy polskiego rolnictwa i konieczności jego ochrony przed obcymi wpływami, zwłaszcza amerykańskim koncernem Monsanto, który jest jednym z największych producentów nasion GMO. Nadawcy komunikatów GTNT stosują także mniej wyszukane taktyki wpływania na emocje odbiorców, np. stosowanie nasyconych afektywnie nawoływań, („Wyrzućmy Roundup z Europy!"), podobnie jak ma to miejsce w prasie bulwarowej.

Ostatnia zasada - opowieści - kładzie nacisk na rolę odpowiedniej narracji w angażowaniu ludzi w naukę i technologię. Julie Downs (2014) pokazuje, że zastosowanie opowieści w komunikacji naukowej pozwala na ukazanie bezpośredniego związku między nauką a życiem tzw. „zwykłych” ludzi. Historie, jakie znalazłam na stronie GTNT, odnoszą się do konkretnych ludzi, którzy w jakiś sposób ucierpieli w wyniku kontaktu z GMO, lub też są ofiarami wielkiego biznesu korporacyjnego. Na przykład historia francuskiego rolnika, który procesował się z Monsanto. Rolnik twierdził, że jeden z herbicydów produkowanych przez Monsanto, którego używał na swojej farmie, spowodował u niego nieodwracalne urazy neurologiczne. Po trwającym trzy lata procesie rolnik wygrał sprawę. Historia ta ma wszystkie elementy "good news" z dziennikarskiego punktu widzenia: jest niezwykła, sensacyjna, spersonalizowana i zaprezentowana w klasycznym stylu walki dobra ze złem.

\section{Zakończenie}

Przedstawiona wyżej analiza pełni jedynie funkcję ilustracyjną i z całą pewnością nie wyczerpuje możliwości, jakie oferują szerzej zakrojone analizy komunikacji. Celem badania było sprawdzenie czy zasady zalecane w popularyzacji wiedzy naukowej w mediach społecznościowych obecne są również w odniesieniu do działań osób podważających tę wiedzę. Jak widać na przykładzie przeglądu strony Facebooka jednej z inicjatyw społecznych sprzeciwiających się GMO, wszystkie zasady poprawnej i udanej komunikacji naukowej określonej w modelu SUCCESS są obecne w działaniach GTNT. Nie świadczy to jednak o doskonałej znajomości tych zasad z literatury (wniosek taki należałoby potwierdzić w wywiadach z przedstawicielami GTNT), ale raczej, jak sądzę, o dużych umiejętnościach wykorzystywania nowych narzędzi komunikacyjnych, jakie oferuje współcześnie internet, i o intuicyjnym rozumieniu potrzeb odbiorcy (krótki, prosty, emocjonalnie nasycony przekaz). Innym czynnikiem, który odgrywa rolę w kształtowaniu postaw wobec nowej technologii w komunikacji internetowej, jest tzw. efekt arogancji (nasty effect). Amerykańscy 
naukowcy (Anderson, Brossard, Scheufele, Xenos, \& Ladwig, 2014) przeprowadzili ciekawy eksperyment, by sprawdzić, czy i w jaki sposób negatywne komentarze wpływają na postrzeganie ryzyka związanego ze stosowaniem nanotechnologii. W tym celu najpierw zamieszczono neutralny wpis na blogu na temat nanotechnologii i poproszono czytelników o ocenę ryzyka związanego z jej wykorzystaniem. Następnie do artykułu dodane zostały wulgarne, aroganckie komentarze, co, jak się okazało, spowodowało, że zaczęto oceniać nanotechnologię jako bardziej ryzykowną.

Z jednej strony media społecznościowe pozwalają włączać w komunikację naukową różnorodne opinie w kwestiach naukowo-technicznych, które rzadko prezentowane są w mediach tradycyjnych, ale z drugiej strony, jak wspominałam wcześniej, specyfika algorytmów, jakimi posługuje się Facebook, Twitter czy YouTube, powoduje, że internauci często odbierają tylko te informacje, które są zgodne z ich wcześniejszymi opiniami, w tym wypadku na temat GMO. Innymi słowy social media nie służą jako miejsce do dyskusji, ale jako miejsce, gdzie osoby opowiadające się za lub przeciwko GMO potwierdzają swoje opinie. Badania pokazują na przykład, że Twitter jest wykorzystywany przede wszystkim do dzielenia się (udostępniania) informacjami wśród ludzi podobnie myślących, a nie do inicjowania debaty na dany temat (Smith, Zhu, Lerman, \& Kozareva, 2013). Na obserwowanej przeze mnie stronie można również zauważyć bardzo niewielką polaryzację opinii na temat GMO. Ci, którzy kwestionują zamieszczane na stronie dane i informacje (jedna osoba), są zazwyczaj ignorowani.

Wydaje się niemal pewne, że nowe narzędzia technologiczne wymuszą zmianę dynamiki komunikacji naukowej oraz włączanie i uwzględnianie w coraz większym stopniu głosów aktorów (nie tylko osób, ale też organizacji) niezwiązanych profesjonalnie z uprawianiem nauki. Jak dotąd naukowcy, eksperci oraz dziennikarze związani z komunikacją naukową zdają się raczej ignorować te alternatywne głosy. Nie oznacza to koniecznie ich złej woli, ale raczej dominację oświeceniowego paradygmatu nauki, w którym prym wiodą eksperci. Jeśli organizowane są konsultacje społeczne, np. w związku z wprowadzeniem nowych regulacji dotyczących GMO, to i tak punktem odniesienia jest zawsze dominujący dyskurs naukowy na ten temat. To prowadzi do sytuacji, w której, jak słusznie zauważa Piotr Stankiewicz (2011), każde takie spotkanie zostaje zredukowane do rozmowy o faktach (naukowych), podczas gdy tematy takie jak wartości, interes polityczny, obawy i niepokoje związane z rozwojem danej technologii zostają przemilczane i wykluczane z debaty. Badania komunikacji naukowej w środowisku online pozwalają więc nie tylko doreprezentować 
nowych aktorów i ich opinie, rzadko obecne w mediach tradycyjnych, ale także zwracają uwagę na wiele niuansów i czynników, które wpływają na ten rodzaj komunikacji.

\section{Bibliografia}

Anderson, A. A., Brossard, D., Scheufele, D. A., Xenos, M. A., \& Ladwig, P. (2014). The "nasty effect": Online incivility and risk perceptions of emerging technologies. Journal of ComputerMediated Communication, 19(3), 373-387. https://doi.org/10.1111/jcc4.12009

Berger, J., \& Milkman, K. L. (2012). What makes online content viral? Journal of Marketing Research, 49(2), 192-205. https://doi.org/10.1509/jmr.10.0353

Bucchi, M. (2004). Can genetics help us rethink communication?: Public communication of science as a 'double helix'. New Genetics and Society, 23(3), 269-283. https://doi. org/10.1080/1463677042000305048

Bucchi, M., \& Mazzolini, R. G. (2003). Big science, little news: Science coverages in the Italian daily press. Public Understanding of Science, 12(1), 7-24. https://doi.org/10.1177/0963662503012001413

Centrum Badania Opinii Społecznej. (2013). Polacy o bezpieczeństwie żywności i GMO. Komunikat nr 4760. Centrum Badania Opinii Społecznej.

Chaffee, S. H., \& Metzger, M. J. (2001). The end of mass communication? Mass Communication \& Society, 4(4), 365-379. https://doi.org/10.1207/S15327825MCS0404_3

Christensen, L. L. (2007). The hands-on guide for science communicators: A step-by-step approach to public outreach. New York, NY: Springer.

Cialdini, R. (1996). Wywieranie wpływu na ludzi: Teoria i praktyka (B. Wojciszke, Tłum.). Gdańsk: Gdańskie Wydawnictwo Psychologiczne.

Choudchury, M., Morris, M., \& White, R. (2014). Seeking and sharing health information online: Comparing search engines and social media. Microsoft Research, One Microsoft Way. Pobrano 15 maja 2016, z http://research.microsoft.com/pubs/208026/health_search_chi2014.pdf

Downs, J. S. (2014). Prescriptive scientific narratives for communicating usable science. Proceedings of the National Academy of Sciences, 111(Suppl. 4), 13627-13633. https://doi.org/10.1073/ pnas.1317502111

Europejscy Zieloni: Proces oceny GMO w UE jest wadliwy. (2016, kwiecień 1). Zielone Wiadomości. Pobrano 15 maja 2016, z http://zielonewiadomosci.pl/tematy/ekologia/europejscy-zieloni -proces-oceny-gmo-w-ue-jest-wadliwy/

GMO To Nie To. (b.d.). Informacje [Strona na Facebooku]. Pobrano 26 lutego 2015, z https:// www.facebook.com/pg/GMOtoNieTo/about/

Heath, C., \& Heath, D. ( 2007). Made to stick: Why some ideas take hold and others come unstuck. New York, NY: Random House. 
Kulczycki, E. (2012, grudzień, 9). Komunikacja naukowa, czyli co? [Wpis na blogu]. Pobrano 15 maja 2016, z http://ekulczycki.pl/teoria_komunikacji/komunikacja-naukowa-czyli-co/

National Science Board. (2014). Science and engineering indicators 2014. Arlington, VA: National Science Foundation.

Plous, S. (1993). The psychology of judgment and decision making. New York, NY: McGraw-Hill. Smith, L. M., Zhu, L., Lerman, K., \& Kozareva, Z. (2013). The role of social media in the discussion of controversial topics. W 2013 International Conference on Social Computing (SocialCom) (ss. 236-243). IEEE. https://doi.org/10.1109/SocialCom.2013.41

Stankiewicz, P. (2011). Od przekonywania do współdecydowania: Zarządzanie konfliktami wokół ryzyka i technologii. Studia Socjologiczne, 203(4), 95-119.

TNS Global. (2016). Wiarygodne informacje?: Czy sq dziś w cenie? Raport. Pobrano 15 maja 2016, z http://www.tnsglobal.pl/archiwumraportow/2016/05/05/wiarygodne-informacje-czy-sadzis-w-cenie-2/\#more-6492

Toczyski, P. (2014). O sednie terminu social media: Web 2.0 a sprawność użytkowników W „generowaniu treści". Kultura Popularna, 2014(3(41)), 56-67.

Vaughan, M. (2013). The thinking effect: Rethinking thinking to create great leaders and the new value worker. Boston, MA: Nicholas Brealey Publishing.

Yeo, S. K. (2015). Public engagement with and communication of science in a Web-2.0 media environment. Washington, DC: The American Association for the Advancement of Science (AAAS).

\section{The influence of the social media on science communication: strategies of GMO opponents on Facebook}

The aim of the article is to discuss a growing role of the social media in science communication. Unlike in traditional mass media - TV, radio, press - the Web 2.0 tools allow to convey a much wider representation of opinions on science and technology, including those opposing or questioning the mainstream research. This paper presents the strategies of communication used by one of the biggest Polish anti-GMO groups on Facebook ("GMO To Nie To") to raise their arguments and gain public support. It concludes that the use of new communication tools such as the social media introduces inevitable changes in the dynamic of science communication, which opens new research opportunities.

\section{Keywords:}

GMO, science communication, social media, Facebook 


\title{
Wpływ mediów społecznościowych na komunikację naukową: strategie przeciwników GMO na Facebooku
}

\begin{abstract}
Celem artykułu jest wskazanie na rosnącą rolę mediów społecznościowych w komunikacji naukowej. W przeciwieństwie do mediów tradycyjnych - telewizji, radia i prasy - narzędzia, jakie oferuje Web 2.0, pozwalają na reprezentację daleko bardziej różnorodnych opinii na temat nauki i technologii, również tych, które przeciwstawiają się powszechnie uznawanym wynikom badań lub je kwestionują. W dalszej części artykułu wskazane zostały strategie komunikacyjne największej na polskim Facebooku grupy skupiającej przeciwników GMO („GMO To Nie To"), stosowane, by zyskać wsparcie dla swoich racji i argumentów. Artykuł kończy się konkluzją, że wykorzystanie nowych narzędzi komunikacyjnych, np. mediów społecznościowych, wprowadza nieuchronne zmiany w dynamice komunikacji naukowej, co otwiera jednocześnie nowe możliwości badawcze.
\end{abstract}

\section{Słowa kluczowe:}

GMO, komunikacja naukowa, media społecznościowe, Facebook

\section{Citation:}

Zielińska, I. (2017). Wpływ mediów społecznościowych na komunikację naukową: strategie przeciwników GMO na Facebooku. Adeptus, 2017(10). https://doi.org/10.11649/a.1513 